\title{
SURVEI KESEHATAN HIDUNG PADA MASYARAKAT PESISIR PANTAI BAHU
}

\author{
${ }^{1}$ Andreas R. Tumbol \\ ${ }^{2}$ R. E. C. Tumbel \\ ${ }^{2}$ Ora I. Palandeng
}

\author{
${ }^{1}$ Kandidat Skripsi Fakultas Kedokteran Universitas Sam Ratulangi Manado \\ ${ }^{2}$ Bagian/SMF Telinga Hidung Tenggorok-Bedah Kepala Leher Fakultas Kedokteran \\ Universitas Sam Ratulangi Manado \\ Email: andreas_rexy@yahoo.com
}

\begin{abstract}
Human's health can be affected by environment and human's behaviour. Nose is an important part of human that can be a shield of environmental disadvantages. Thisa study aimed to obtain nose health of people of Bahu coastal area. This was a descriptive observasional study with a cross sectional design. The subjects of this study were people living at Bahu coastal area. There were 31 respondents consisting of 12 men and 19 women. Nose examination showed normal result in 19 respondents and abnormality in 12 respondents. In nasal passage examination, $3.2 \%$ respondents showed narrow nasal cavities. In nasal turbinate examination, swollen conchae were found in $6.5 \%$ of respondents; swollen and pale conchae 6.5\%; swollen, pale, and hypertrophic conchae in right turbinate 3.2\% meanwhile in left turbinate 6.5\%; and swollen, hyperemic, and hypertrophic conchae in right and left turbinate 3.2\%. Hypertrophic conchae in right turbinate was 3.2\% while in left turbinate was $6.5 \%$. Pale and hypertrophic conchae in right and left turbinate was 3.2\%. In nasal mucosa examination, hyperemic mucosa was $3.2 \%$ and bluish mucosa was $16.1 \%$. In secretion examination, serous and mucoid secretion was found among $3.2 \%$ of respondents. In nasal septum examination, septum deviation was found $6.5 \%$ to the right and $3.2 \%$ to the left. Conclusion: Most of the respondents showed normal result
\end{abstract}

Keywords: health survey, nose examination

\begin{abstract}
Abstrak: Kesehatan pada manusia dapat dipengaruhi oleh lingkungan dan perilaku manusia. Hidung merupakan salah satu organ penting yang menjadi pelindung tubuh terhadap lingkungan yang tidak menguntungkan. Penelitian ini bertujuan untuk mengetahui gambaran kesehatan hidung pada masyarakat pesisir pantai Bahu. Desain yang digunakan ialah penelitian deskriptif survei dengan pendekatan potong lintang. Subjek penelitian ialah masyarakat pesisir pantai Bahu. Jumlah responden yang mengikuti penelitian ini 31 orang, terdiri dari 12 laki-laki dan 19 perempuan. Pada hasil pemeriksaan hidung didapatkan hasil normal pada 19 orang dan kelainan pada 12 orang. Pada pemeriksaan kavum nasal, kavum sempit ditemukan 3,2\%. Pada pemeriksaan konka nasal, udim konka nasal 6,5\%; udim dan pucat pada konka nasal 3,2\%; udim, pucat, dan hipertrofi konka nasal kanan 3,2\% dan konka nasal kiri 6,5\%; udim, hiperemis, dan hipertrofi konka nasal 3,2\%; hipertrofi konka nasal kanan 3,2\% dan konka nasal kiri 6,5\%; pucat dan hipertrofi konka nasal 3,2\%. Pada pemeriksaan mukosa nasal, hiperemis mukosa 3,2\%, dan livide mukosa 16,1\%. Pada pemeriksaan sekret, serous dan mukoid 3,2\%. Pada pemeriksaan septum nasal, deviasi septum ke kanan 6,5\% dan ke kiri 3,2\%. Simpulan: Sebagian besar responden penelitian ini memperlihatkan hasil normal
\end{abstract}

Kata kunci: survei kesehatan, pemeriksaan hidung 
Kesehatan adalah sesuatu yang didambakan oleh setiap orang. World

Health Organization mendefinisikan sehat sebagai keadaan fisik, mental, dan sosial yang baik, tidak hanya terbebas dari penyakit, cacat, atau kelemahan. Kesehatan adalah hasil interaksi berbagai faktor internal maupun faktor eksternal. Faktor internal meliputi keadaan fisik dan psikis sedangkan faktor eksternal adalah sosial, budaya, lingkungan, politik, ekonomi, pendidikan, dan sebagainya. Faktor-faktor yang mempengaruhi kesehatan berdasarkan besarnya pengaruh meliputi secara berurutan yaitu faktor lingkungan, faktor perilaku, faktor pelayanan kesehatan, dan faktor keturunan. Faktor keturunan tidak bisa dicegah karena sifatnya adalah warisan dari orangtua atau leluhur. Faktor lingkungan, pelayanan kesehatan, dan perilaku adalah faktor-faktor yang bisa diubah oleh manusia sehingga dapat tercipta kesehatan bagi tiap orang. ${ }^{1,2}$

Faktor lingkungan sangat besar pengaruhnya terhadap status kesehatan. Faktor lingkungan terdiri dari tiga bagian, yaitu lingkungan fisik, lingkungan biologis, dan lingkungan sosial. Lingkungan fisik dapat dilihat dari tempat tinggal seseorang di suatu tempat seperti daerah pegunungan atau daerah pantai, kota atau desa, bersih atau kotor. Lingkungan biologis berupa makhluk hidup lain yang dapat mempengaruhi kesehatan manusia sebagai vektor penyakit. Lingkungan sosial terdiri dari sosio ekonomi, sosio budaya, adat istiadat, kepercayaan, organisasi kemasyarakatan dan lain-lain. ${ }^{1}$

Perilaku manusia dapat mempengaruhi kesehatan manusia. Perilaku kesehatan dipengaruhi oleh tiga faktor yaitu faktor predisposisi, pemungkin, dan pendukung. Faktor predisposisi adalah faktor yang terwujud dalam kepercayaan, keyakinan, nilai-nilai, dan juga variasi demografi seperti status ekonomi, umur, jenis kelamin, dan susunan keluarga. Faktor pemungkin adalah faktor yang terwujud dalam lingkungan fisik, termasuk di dalamnya adalah berbagai macam sarana dan prasarana. Faktor pendukung adalah faktor sikap dan perilaku tokoh masyarakat, tokoh agama, petugas kesehatan. ${ }^{1}$

Hidung merupakan organ yang terlihat kecil namun penting bagi manusia. Hidung merupakan salah satu organ penting yang menjadi pelindung tubuh terhadap lingkungan yang tidak menguntungkan. Hidung terkadang dapat tersumbat oleh karena berbagai penyebab seperti alergi, kelainan anatomi, ataupun massa pada hidung. Penyakit-penyakit yang dapat timbul pada hidung antara lain rinitis alergi maupun vasomotor, deviasi septum, dan polip hidung. $^{3}$

Masyarakat pesisir adalah sekelompok warga yang tinggal di wilayah pesisir yang hidup bersama dan memenuhi kebutuhan hidup dari sumber daya di wilayah pesisir. Jenis mata pencaharian masyarakat pesisir didominasi nelayan dan petani ikan. Masyarakat pesisir yang didominasi oleh usaha perikanan umumnya masih berada pada garis kemiskinan, dan tingkat pendidikan yang rendah. Dalam data riset kesehatan dasar tercatat bahwa nelayan, petani, dan buruh merupakan pekerjaan dengan persentase terbesar sebagai perokok aktif sebesar 44,5\% dibandingkan pekerjaan lainnya. Proporsi perokok setiap hari tampak cenderung meningkat pada kuintil indeks kepemilikan yang lebih rendah seperti pada masyarakat pesisir. ${ }^{4-6}$

Berdasarkan latar belakang tersebut, peneliti tertarik untuk melakukan penelitian survei kesehatan hidung pada masyarakat pesisir pantai, salah satunya masyarakat pesisir pantai Bahu.

\section{METODOLOGI PENELITIAN}

Metode penelitian yang digunakan adalah deskriptif observasional dengan pendekatan cross sectional. Penelitian dilakukan pada 8 November 2014 di pesisir pantai Bahu, Manado. Populasi penelitian adalah masyarakat pesisir pantai Bahu. Sampel penelitian adalah masyarakat pesisir pantai Bahu yang bersedia mengikuti penelitian.

Penelitian ini dilakukan dengan memeriksa hidung responden secara langsung. Data hasil pemeriksaan diisi pada 
tabel pemeriksaan THT yang telah disediakan dan diolah dengan menggunakan Microsoft Word, dan Microsoft Excel.

\section{HASIL PENELITIAN}

Total responden yang mengikuti penelitian berjumlah 31 orang, terdiri dari perempuan dengan jumlah 19 orang (61,3\%) dan sisanya laki-laki dengan jumlah 12 orang (38,7\%). Data hasil pemeriksaan hidung responden yang didapat sebagai berikut.

Tabel 1. Distribusi keadaan kavum nasal pada masyarakat pesisir pantai Bahu

\begin{tabular}{lcccc}
\hline Kavum & \multicolumn{2}{c}{$\mathrm{n}$} & \multicolumn{2}{c}{$\%$} \\
\cline { 2 - 5 } nasi & Kanan & Kiri & Kanan & Kiri \\
\hline Lapang & 30 & 31 & 96,8 & 100,0 \\
\hline Sempit & 1 & 0 & 3,2 & 0,0 \\
\hline Massa & 0 & 0 & 0,0 & 0,0 \\
\hline Total & 31 & 31 & 100,0 & 100,0 \\
\hline
\end{tabular}

Tabel 2. Distribusi keadaan konka pada masyarakat pesisir pantai Bahu

\begin{tabular}{lcccc}
\hline \multirow{2}{*}{$\begin{array}{l}\text { Keadaan } \\
\text { Konka }\end{array}$} & \multicolumn{2}{c}{$\mathrm{n}$} & \multicolumn{2}{c}{$\%$} \\
\cline { 2 - 5 } & Kanan & Kiri & Kanan & Kiri \\
\hline Normal & 24 & 22 & 77,4 & 71 \\
\hline Udim & 2 & 2 & 6,5 & 6,5 \\
\hline $\begin{array}{l}\text { Udim, } \\
\text { pucat }\end{array}$ & 1 & 1 & 3,2 & 3,2 \\
\hline $\begin{array}{l}\text { Udim, } \\
\text { pucat, } \\
\text { hipertrofi }\end{array}$ & 1 & 2 & 3,2 & 6,5 \\
\hline $\begin{array}{l}\text { Udim, } \\
\text { hiperemis, } \\
\text { hipertrofi }\end{array}$ & 1 & 1 & 3,2 & 3,2 \\
\hline Hipertrofi & 1 & 2 & 3,2 & 6,5 \\
\hline $\begin{array}{l}\text { Pucat, } \\
\text { hipertrofi }\end{array}$ & 1 & 1 & 3,2 & 3,2 \\
\hline Total & 31 & 31 & 100,0 & 100,0 \\
\hline
\end{tabular}

Tabel 3. Distribusi keadaan mukosa nasal pada masyarakat pesisir pantai Bahu

\begin{tabular}{lcccc}
\hline \multirow{2}{*}{$\begin{array}{c}\text { Keadaan } \\
\text { mukosa }\end{array}$} & \multicolumn{2}{c}{$\mathrm{n}$} & \multicolumn{2}{c}{$\%$} \\
\cline { 2 - 5 } & Kanan & Kiri & Kanan & Kiri \\
\hline Normal & 25 & 25 & 80,6 & 80,6 \\
\hline Hiperemis & 1 & 1 & 3,2 & 3,2 \\
\hline Livide & 5 & 5 & 16,1 & 16,1 \\
\hline Total & 31 & 31 & 100,0 & 100,0 \\
\hline
\end{tabular}

Tabel 4. Distribusi berdasarkan adanya sekret pada masyarakat pesisir pantai Bahu

\begin{tabular}{lcccc}
\hline \multirow{2}{*}{ Sekret } & \multicolumn{2}{c}{$\mathrm{n}$} & \multicolumn{2}{c}{$\%$} \\
\cline { 2 - 5 } & Kanan & Kiri & Kanan & Kiri \\
\hline Tidak Ada & 30 & 30 & 96,8 & 96,8 \\
\hline $\begin{array}{l}\text { Serous } \\
\text { dan }\end{array}$ & 1 & 1 & 3,2 & 3,2 \\
Mukoid & & & & \\
\hline Purulen & 0 & 0 & 0,0 & 0,0 \\
\hline Total & 31 & 31 & 100,0 & 100,0 \\
\hline
\end{tabular}

Tabel 5. Distribusi keadaan septum nasal pada masyarakat pesisir pantai Bahu

\begin{tabular}{lcccc}
\hline \multirow{2}{*}{$\begin{array}{c}\text { Septum } \\
\text { nasal }\end{array}$} & \multicolumn{2}{c}{$\mathrm{n}$} & \multicolumn{2}{c}{$\%$} \\
\cline { 2 - 5 } & Kanan & Kiri & Kanan & Kiri \\
\hline Normal & 29 & 30 & 93,5 & 96,8 \\
\hline Deviasi & 2 & 1 & 6,5 & 3,2 \\
\hline Abses & 0 & 0 & 0,0 & 0,0 \\
\hline Hematoma & 0 & 0 & 0,0 & 0,0 \\
\hline Total & 31 & 31 & 100,0 & 100,0 \\
\hline
\end{tabular}

Tabel 6. Distribusi berdasarkan post nasal drips pada masyarakat pesisir pantai Bahu

\begin{tabular}{ccccc}
\hline & \multicolumn{2}{c}{$\mathrm{n}$} & \multicolumn{2}{c}{$\%$} \\
\cline { 2 - 5 } $\begin{array}{c}\text { Post } \\
\text { nasal } \\
\text { drips }\end{array}$ & Kanan & Kiri & Kanan & Kiri \\
\hline Ada & 0 & 0 & 0,0 & 0,0 \\
\hline $\begin{array}{c}\text { Tidak } \\
\text { ada }\end{array}$ & 31 & 31 & 100,0 & 100,0 \\
\hline Total & 31 & 31 & 100,0 & 100,0 \\
\hline
\end{tabular}

\section{BAHASAN}

Penelitian suvei kesehatan pada masyarakat pesisir pantai Bahu menggunakan 31 sampel dengan sampel terbanyak adalah perempuan dengan persentase $61,3 \%$. Karakteristik pekerjaan terbanyak pada sampel penelitian adalah ibu rumah tangga dengan persentase 41,9\%. Pemeriksaan hidung dilakukan pada semua responden.

Pada pemeriksaan kavum nasal pada masyarakat pesisir pantai Bahu, didapatkan hasil sebagian besar normal pada sampel dengan persentase 96,8\%. Masalah pada kavum nasal yang ditemukan adalah kesempitan pada kavum nasal kanan pada satu orang dengan persentase 3,2\%. Kavum nasi dapat menjadi sempit salah satunya 
karena polip nasal. Polip nasal adalah massa lunak yang mengandung banyak cairan di dalam rongga hidung, berwarna putih keabu-abuan, yang terjadi akibat inflamasi mukosa. Polip dapat timbul pada laki-laki ataupun perempuan, dari usia anak-anak hingga usia lanjut. ${ }^{7}$

Pada pemeriksaan konka nasal pada masyarakat pesisir pantai Bahu, didapatkan hasil sebagian besar normal pada sampel dengan persentase $77,4 \%$ pada konka nasal kanan dan $71 \%$ pada konka nasal kiri. Keadaan abnormal yang bervariasi ditemukan pada konka nasal kanan dan kiri. Udim pada konka nasal merupakan keadaan abnormal terbanyak pada konka nasal kanan dengan jumlah 2 orang (6,5\%). Keadaan abnormal lain mempunyai distribusi yang merata dengan jumlah 1 orang (3,2\%). Keadaan abnormal lain meliputi keadaan udim disertai pucat, keadaan udim disertai pucat dan hipertrofi, keadaan udim disertai hiperemis dan hipertrofi, keadaan pucat disertai hipertrofi, dan keadaan hipertrofi. Pada konka nasal kiri, keadaan udim, keadaan udim disertai pucat dan hipertrofi, dan keadaan hipertrofi merupakan keadaan abnormal terbanyak dengan jumlah 2 orang (6,5\%). Keadaan abnormal lain tersebar merata dengan jumlah 1 orang (3,2\%). Keadaan abnormal lain meliputi keadaan udim disertai pucat, keadaan udim disertai hiperemis dan hipertrofi, dan keadaan hipertrofi. Udim dan hiperemis pada konka dapat ditemukan pada keadaan inflamasi seperti rinitis. Hiperemis terjadi karena vasodilatasi kapiler-kapiler pada hidung akibat proses inflamasi. Konka tampak pucat karena konka mengandung banyak cairan dan sedikit aliran darah yang masuk. Hipertrofi konka merupakan istilah yang diperkenalkan pertama kali tahun 1800 yang diartikan sebagai pembesaran konka inferior dan istilah ini masih dipakai sampai sekarang. Hipertrofi adalah pembesaran dari organ atau jaringan karena ukuran selnya yang meningkat. Penyebab hipertrofi konka adalah rinitis alergi, rinitis vasomotor, dan kompensasi dari septum deviasi kontralateral. ${ }^{8}$
Pada pemeriksaan mukosa nasal pada masyarakat pesisir pantai Bahu, didapatkan hasil sebagian besar normal pada sampel dengan persentase $80,6 \%$. Keadaan livide pada nasal merupakan keadaan abnormal terbanyak pada mukosa nasal kanan dan kiri. Livide mukosa nasal ditemukan pada 5 orang (16,1\%). Keadaan hiperemis pada mukosa nasal ditemukan hanya pada 1 orang (3,2\%). Mukosa hiperemis terjadi pada keadaan inflamasi seperti rinitis. Mukosa livide atau pucat terjasi karena cairan pada mukosa banyak dan menyebabkan aliran darah ke mukosa menjadi sedikit.

Pada pemeriksaan sekret pada masyarakat pesisir pantai Bahu, didapatkan hasil sebagian besar normal pada sampel dengan persentase 96,8\%. Sekret hanya ditemukan pada 1 orang (3,2\%) pada nasal kanan dan kiri. Jenis sekret yang ditemukan merupakan sekret serous dan mukoid. Sekret serous merupakan jenis sekret yang terdiri atas protein pembuluh darah yang bocor dari pembuluh darah yang permeabel yang biasa terjadi pada kasus alergi. Sekret mukoid dapat terjadi karena aktivitas yang berlebihan dari sel goblet. Sekret purulen dapat terjadi karena adanya infeksi bakteri.

Pada pemeriksaan septum nasal pada masyarakat pesisir pantai Bahu, didapatkan hasil sebagian besar normal pada sampel dengan persentase $93,5 \%$ pada septum nasal kanan dan 96,8\% pada septum nasal kiri. Kelainan pada septum yang ditemukan hanya deviasi septum. Deviasi septum nasal kanan ditemukan pada 2 orang (6,5\%) sedangkan deviasi septum kiri ditemukan pada 1 orang (3,2\%). Deviasi septum adalah septum yang membengkok, dapat terjadi karena trauma pada hidung. Abses adalah kumpulan pus atau nanah yang dapat terjadi karena infeksi yang kronis pada hidung. Hematoma terjadi karena darah yang berada di luar pembuluh darah terkumpul pada satu tempat. ${ }^{9}$

Pada pemeriksaan post nasal drips masyarakat pesisir pantai Bahu, tidak ditemukan adanya post nasal drips baik pada nasal kanan maupun kiri. 


\section{SIMPULAN}

Survei kesehatan hidung yang dilakukan pada masyarakat pesisir pantai Bahu meliputi pemeriksaan kavum nasal, konka nasal, mukosa nasal, septum nasal, sekret, dan post nasal drips. Sebagian besar responden yang diperiksa pada survei kesehatan hidung memiliki hasil normal.

\section{SARAN}

Saran dari peneliti adalah untuk melakukan upaya penyuluhan kesehatan telinga, hidung, dan tenggorok kepada masyarakat pesisir pantai untuk meningkatkan kesehatan telinga, hidung, dan tenggorok pada masyarakat pesisir pantai, dan untuk melakukan survei kesehatan hidung pada orang-orang yang sering terpapar oleh polutan udara.

\section{DAFTAR PUSTAKA}

1. Maulana H. Promosi kesehatan. Jakarta: EGC,2009. p.7-10, 226

2. WHO. Health [homepage on internet].[cited 11 Desember 2014]. Available from : http://who.int/trade/glossary/story046/e $\mathrm{n} /$

3. Hilger PA. Hidung: anatomi dan fisiologi terapan. Dalam: Adams GL, Boies LR, Higler PA. Boies buku ajar penyakit tht. Edisi 6 . Jakarta: EGC, 1997.p.173-88

4. Prianto E. Proseding fenomena aktual tema doktoral arsitektur dan perkotaan. Semarang: Badan Penerbit Universitas Diponegoro. 2005

5. Lewaherilla NE. Pariwisata bahari: pemanfaatan potensi wilayah pesisir dan lautan. Makalah Pasca Sarjana. Bogor: Institut Pertanian Bogor. 2002

6. Indonesia. Kementerian Kesehatan. Riset Kesehatan Dasar tahun 2013. Jakarta: Badan penelitian dan Pengembangan Republik Indonesia tahun; 2013.

7. Adams GL, Boies LR, Higler PH. Boies buku ajar penyakit tht. Edisi 6. Jakarta: EGC, 1997.p. 246-7

8. Former SEJ, Eccles R. Chronic inferior turbinate enlargement and implications for surgical intervention. Rhinology 2006; 44:234-8

9. Nizar NW, Mangunkusumo E. Kelainan septum. Dalam: Soepardi EA, Iskandar $\mathrm{N}$, Bashiruddin J, Restuti RD. Buku ajar ilmu kesehatan telinga hidung tenggorok. Edisi 7. Jakarta: Balai penerbit FKUI, 2012. p. 104-5 